REFLEKSI HUKUM

Jurnal Imu Hukum
p-ISSN 2541-4984 | e-ISSN 2541-5417

Volume 6 Nomor 1, Oktober 2021, Halaman 37-52

DOI: https:// doi.org/10.24246/jrh.2021.v6.i1.p37-52

Open access at: http:// ejournal.uksw.edu/refleksihukum

Penerbit: Fakultas Hukum Universitas Kristen Satya Wacana

\title{
KEKUATAN EKSEKUSI JAMINAN LETTER OF UNDERTAKING PADA PEMBIAYAAN PERBANKAN
}

\section{Rio Christiawan}

Fakultas Hukum Universitas 17 Agustus 1945 Jakarta | rchristiawan@gmail.com

\section{A R T I C L E I N F O \\ Article history: \\ Received \\ 16 Agustus 2021 \\ Revised \\ 2 Oktober 2021 \\ Accepted \\ 25 November 2021 \\ Kata-kata Kunci: \\ Jaminan khusus; Perjanjian kredit; LoU; Upaya terbaik.}

\section{Keywords:}

Special collateral;

Credit agreement; LoU;

Best effort.

\begin{abstract}
Abstrak
Dalam perjanjian kredit sering kali digunakan letter of undertaking (LoU) sebagai jaminan khusus untuk menjamin pembiayaan yang diberikan oleh bank selaku kreditur. Dengan jaminan LoU maka berdasarkan Pasal 1134 Kitab Undang-Undang Hukum Perdata (KUH Perdata) kedudukan bank sebagai kreditur akan lebih tinggi dari kreditur lainnya. Persoalan hukum yang hendak dibahas terkait kekuatan eksekutorial dari jaminan LoU dalam hal nasabah debitur tidak mampu memenuhi kewajibannya. Metode penelitian adalah yuridis normatif dengan pengambilan data secara kepustakaan dengan cara berpikir deduktif dalam melakukan verifikasi data. Temuan dalam penelitian ini adalah LoU dipandang sebagai bentuk jaminan khusus seharusnya bank sebagai kreditur dapat melakukan eksekusi atas jaminan tersebut untuk melunasi kewajiban pembiayaan yang tidak dapat dipenuhi oleh nasabah debitur.
\end{abstract}

\footnotetext{
Abstract

The credit agreements often use Letters of Undertaking (LoU) to guarantee the financing provided by banks as creditors. Based on Article 1134 of the Indonesian Civil Code, the LoU gives the banks a higher position instead of other creditors. This article discusses a legal issue related to the legal enforcement of the LoU in the event the debtor fails to fulfill his obligations. This article used the normative-juridical method by literacy data collection and the deductive-thinking in data verification. In the finding, the LoU is seen as a special instrument for the banks as creditors to perform the execution of collateral to pay off the financing obligation, which is failed to be fulfilled by the debtor.
} 


\section{PENDAHULUAN}

Dalam praktik bisnis berkembang jaminan untuk perjanjian kredit yang dikenal dengan istilah letter of undertaking (LoU). Penggunaan LoU bersifat menguntungkan debitur karena tidak memerlukan aset tertentu untuk dijaminkan seperti pada jaminan hak tanggungan atau fidusia. Harvard Business Law Dictionary, mendefinisikan LoU: "an assurance by one party to another party that they will fulfill the obligation that had been previously agreed on, but not written into a contract". ${ }^{1}$ Dalam definisi tersebut tampak bahwa pihak yang menerbitkan LoU adalah bukan debitur, namun pihak yang menjamin utang yang ditimbulkan oleh debitur dan menjamin pengembalian piutang kreditur.

LoU sebagai jaminan perjanjian pembiayaan memiliki padanan dengan Pasal 1317 KUH Perdata. ${ }^{2}$ Dalam hal ini LoU diterbitkan oleh penjamin untuk menjamin terpenuhinya pengembalian piutang kreditur. Namun persoalannya jika tujuan LoU adalah menjamin pengembalian (repayment) maka seharusnya dalam LoU disebutkan jumlah dan komitmen secara pasti. Namun sebaliknya dalam LoU hanya disebutkan bentuk upaya terbaik (best effort). Hal ini merupakan implikasi dari definisi "... but not written into a contract" yang memiliki makna tidak adanya bentuk baku dari penuangan komitmen yang dibuat penjamin selaku penanggung kewajiban nasabah debitur. Akibatnya kekuatan hukum LoU menjadi multitafsir dan tidak memberikan kepastian hukum bagi bank sebagai kreditur. Secara faktual dalam kurun waktu lima tahun terakhir (2015-2019) tidak satupun dari bank Himbara (Himpunan Bank Pemerintah/Bank BUMN) yang berhasil melakukan eksekusi untuk pemenuhan kewajiban debitur melalui LoU, upaya ini sudah dilakukan baik di pengadilan konvensional maupun melalui jalur arbitrase. ${ }^{3}$

Ketidakpastian hukum juga nampak dalam sikap mendua Mahkamah Agung (MA). Putusan MA Nomor 1150/K/Pdt/2015 menyatakan bahwa LoU dapat dieksekusi sepanjang menyebutkan jumlah dan sifat penanggungan yang diberikan penjamin secara pasti. Jika tidak disebutkan secara pasti maka sesuai dengan Pasal 1824 Kitab Undang-Undang Hukum Perdata, tanggung jawab penanggung adalah tidak dapat dipersangkakan tetapi harus dinyatakan secara tegas. ${ }^{4}$ Berbeda dengan itu, Putusan MA Nomor 1496/K/Pdt/2018 menyatakan bahwa LoU hanya memiliki sifat eksekusi berdasarkan upaya terbaik (best effort) sehingga tidak dapat menggambarkan jumlah pengembalian (repayment) kepada kreditur secara jelas, artinya penjamin tidak memiliki kewajiban untuk melakukan pengembalian (repayment) sejumlah nilai yang menjadi kegagalan bayar oleh debitur.

Berdasarkan penjelasan di atas, artikel ini bermaksud mendiskusikan isu

Morisson, et. al, Harvard Business Law Dictionary (ed. 1, Harvard Book Publishing 2000) 127.

Pasal 1317 KUH Perdata mengatur tentang janji yang dibuat pihak ketiga, dalam hal ini penjamin (penanggung) yang menjamin terpenuhinya perjanjian kredit pembiayaan yang dibuat debitur dan kreditur.

3 Bank Himbara dan otoritas jasa keuangan (OJK), 'Notulen rapat kerja antara bank Himbara dengan otoritas jasa keuangan (OJK), dengan agenda tindak lanjut non performing loan (NPL)' (Bank Himbara dan OJK, Jakarta, 15 Januari 2020).

4 Dalam hal ini jika mengacu pada Pasal 1824 KUH Perdata bahwa tanggung jawab penanggung tidak dapat dipersangkakan artinya harus disebutkan secara konkret, tegas, dan jelas. Artinya jika kewajiban penjamin ditentukan secara tegas maka bank dapat melakukan eksekusi sukarela pada penjamin maupun jika dilakukan melalui pengadilan maka akan dapat dilakukan eksekusi sesuai jumlah yang disebutkan di dalam LoU. 
hukum tentang kekuatan eksekusi jaminan LoU pada pembiayaan perbankan. Dalam konteks demikian maka pertanyaan spesifik yang hendak dijawab di sini adalah apakah secara hukum LoU layak disebut sebagai jaminan khusus? Artikel ini berargumen bahwa LoU hanya dipandang janji dari penerbit LoU sebagai penjamin namun janji tersebut bersifat abstrak karena tidak disertai dengan nilai pertanggungjawaban absolut dari penjamin. Menurut teori hukum jaminan pembiayaan, salah satu ciri sebuah jaminan dapat dikatakan sebagai jaminan khusus selain dapat dalam jaminan tersebut menunjuk pada perjanjian utang piutang antara para pihak, sifat jaminan tersebut juga harus memenuhi sifat claim on demand. Pengertian claim on demand dalam hal ini adalah jaminan khusus tersebut dapat serta-merta dipergunakan sebagai pengembalian atas piutang kreditur. ${ }^{5}$ Artinya ada jumlah absolut yang dijamin melalui jaminan khusus tersebut.

\section{PEMBAHASAN}

\section{Kedudukan Jaminan Letter of Undertaking (LoU)}

LoU pada prinsipnya merupakan penjaminan yang dikenal dalam Pasal 1820 dan Pasal $1821 \mathrm{KUH}$ Perdata, yakni suatu perikatan yang dibuat oleh pihak ketiga guna kepentingan kreditur mengikatkan diri untuk memenuhi kepentingan debitur ketika debitur tidak memenuhi kewajibannya. ${ }^{6}$ Permasalahan terkait sifat jaminan LoU disebabkan karena dalam praktiknya LoU tidak memiliki bentuk baku dan hanya berdasarkan pada pertanggungjawaban upaya terbaik (best effort).

LoU berasal dari sistem hukum Anglo Saxon yang diterapkan dalam praktik perbankan di Indonesia, sehingga dalam hal inilah LoU tidak dapat memenuhi unsur jaminan khusus maupun jaminan umum yang ada dalam KUH Perdata. ${ }^{7}$ LoU jelas merupakan jaminan khusus, meskipun tidak memenuhi syarat jaminan khusus sebagaimana diatur dalam KUH Perdata. LoU dalam pembiayaan perbankan dimaknai sebagai bentuk jaminan dari pihak ketiga sebagai penjamin pembiayaan yang diajukan oleh nasabah debitur dan pertanggungjawaban dalam LoU akan timbul seketika pada saat nasabah debitur tidak dapat memenuhi kewajiban yang diperjanjikan pada kreditur. ${ }^{8}$

LoU dikatakan jaminan yang relatif menguntungkan debitur karena dalam LoU tidak diatur mengenai nilai absolut yang menjadi tanggung jawab dari penjamin, namun penjamin tetap bertanggung jawab atas perikatan yang dibuat nasabah debitur, jika nasabah debitur tidak memenuhi kewajibannya. Dalam praktik pembiayaan di negara Common Law, LoU hanya dipergunakan sebagai jaminan pendukung karena nilai jaminan dari nasabah debitur telah memenuhi rasio kecukupan jaminan (security coverage ratio).

LoU dalam pembiayaan di negara Common Law hanya bersifat sebagai sponsor

Hoogan Peter, Legal Aspect on Financing Transaction (ed. 5, Little Brown Publishing 2009) 111. Yudha Ramelan, 'Perlindungan terhadap Simpanan Pernah Tercatat pada Bank, Bukan Suatu Keniscayaan' (2019) 49 (4) Jurnal Hukum dan Pembangunan Universitas Indonesia 789, 792. Gunarto Suhardi, Usaha Perbankan dalam Perspektif Hukum (cet. 1, Kanisius 2003) 73.

Yessy Kusumadewi, 'Pelaksanaan Prinsip Piercing The Corporate Veil dalam Perseroan Terbatas menurut Undang-Undang Nomor 40 Tahun 2007 tentang Perseroan Terbatas’ (2019) 8 (1) Jurnal Ilmu Hukum: Binamulia Hukum 79, 83. 
dalam pembiayaan yang diajukan oleh nasabah debitur, oleh karena itu sifat dari jaminan LoU bersifat off balance sheet. ${ }^{9}$ Dalam hal ini pengertian sebagai sponsor adalah penjamin yang bertindak sebagai sponsor biasanya memiliki name landing atau nama yang premium pada dunia perbankan memberikan jaminan dalam bentuk undertaking dari pembiayaan yang diajukan nasabah debitur.

Secara hukum, pernyataan sponsorship hanya melahirkan tanggung jawab upaya terbaik dalam bentuk undertaking (best effort). Idealnya memang LoU hanya dipergunakan sebagai jaminan pelengkap untuk menambah keyakinan bank bahwa ada premium name landing yang menjadi penjamin dalam perjanjian pembiayaan antara debitur dan kreditur. Jadi sifat LoU pada esensinya adalah untuk menambah keyakinan kreditur dalam hal rasio kecukupan jaminan terhadap pinjaman (security coverage ratio) telah memenuhi syarat.

LoU secara hukum bersifat off balance sheet, berarti tidak dicatatkan dalam laporan keuangan pemberi jaminan (termasuk berlaku bagi penjamin yang berstatus sebagai perusahaan terbuka). Dikatakan sebagai off balance sheet karena nilai absolut yang menjadi tanggung jawab dari pemberi jaminan tidak dapat ditentukan secara pasti, mengingat secara hukum 'undertaking' hanya akan melahirkan pertanggungjawaban berdasarkan upaya terbaik.

Secara hukum ada perbedaan antara undertaking dan guarantee dalam pembiayaan perbankan, dimana undertaking merupakan bentuk jaminan pelengkap tanpa nilai absolut yang harus dibayarkan oleh penjamin dalam hal nasabah debitur tidak dapat memenuhi kewajibannya. Sebaliknya guarantee adalah bentuk jaminan dengan nilai absolut yang dipertanggungjawabkan oleh penjamin dalam hal nasabah debitur tidak dapat memenuhi kewajiban yang timbul dari perjanjian pembiayaan antara debitur dan kreditur.

Perbedaan undertaking dan guarantee lainnya adalah sifat perlindungan keduanya yang berbeda secara hukum pada kepentingan bank selaku kreditur. Pada garansi (guarantee) ${ }^{10}$, karena ada nilai absolut yang menjadi pertanggungjawaban penjamin ketika nasabah debitur tidak dapat memenuhi kewajibannya maka berlaku prinsip claim on demand. Sebaliknya pada undertaking karena hanya melahirkan pertanggungjawaban berdasarkan upaya terbaik (best effort) maka tidak berlaku prinsip claim on demand.

LoU tetaplah merupakan jaminan dalam hukum perbankan, karena LoU merupakan jaminan dari pihak ketiga (sebagai penjamin) kepada bank untuk memberikan pembiayaan pada nasabah debitur. Penggunaan LoU sebagai jaminan dalam praktik perbankan pada esensinya memenuhi unsur penanggungan (borgtocht) sebagaimana disebutkan dalam Pasal 1820 dan 1821 KUH Perdata. ${ }^{11}$ Jadi dalam hal ini meskipun bersifat undertaking tapi kedudukan LoU secara hukum tetap dapat dipandang sebagai jaminan meskipun tanpa nilai absolut.

LoU dalam praktik perbankan di Indonesia secara hukum tetap dapat dipandang sebagai jaminan karena LoU yang dipersyaratkan sebagai jaminan dalam

9 Suwinto Johan dan Ariawan, 'Keterbukaan Informasi UU Pasar Modal Menciptakan Asymmetric Information dan Semi Strong Form' (2021) 50 (1) Jurnal Masalah-masalah Hukum Universitas Diponegoro 106, 107.

10 Rahmi Jened, 'Catatan Hukum Kritis Pembiayaan Sekunder Perumahan' (2019) 31 (1) Jurnal Mimbar Hukum Universitas Gadjah Mada 15, 17.

11 Nurul Elmiyah dan Suparjo Sujadi, 'Upaya-upaya Hukum terhadap Penetapan' (2005) 35 (3) Jurnal Hukum dan Pembangunan Universitas Indonesia 326, 326-350. 
perjanjian pembiayaan akan dicantumkan dalam klausula syarat penandatanganan perjanjian kredit dalam surat penawaran pembiayaan yang diterbitkan oleh bank (offering letter).

Dalam naskah pembahasan Peraturan Otoritas Jasa Keuangan Nomor 40/POJK.03/2019 disebutkan bahwa LoU merupakan bentuk jaminan dalam praktik pemberian kredit pembiayaan perbankan, demikian juga dalam naskah akademik tersebut juga disebutkan bahwa belum ada formulasi penilaian LoU sebagai jaminan secara baku sehingga penggunaan LoU cenderung subjekif. ${ }^{12}$

Penggunaan LoU sebagai jaminan perbankan juga disebutkan dalam konvensi perbankan dan pembiayaan internasional dalam Bassel Convention 1999, disebutkan bahwa jika nasabah debitur telah memiliki tingkat risiko (risk rating) $\mathrm{BBB}+$ maka bank boleh memberikan pembiayaan dengan jaminan LoU. Dalam Article 26 Basel Convention disebutkan bahwa LoU meskipun bersifat undertaking tetapi secara hukum tetap berlaku sebagai jaminan untuk menjamin pembiayaan nasabah dengan tingkat risiko $\mathrm{BBB}+$.

Dalam praktik perbankan di Indonesia, dalam hal ini baik nasabah sebagai debitur maupun bank sebagai kreditur telah menyadari kedudukan LoU sebagai jaminan karena dalam surat penawaran pembiayaan yang diterbitkan oleh bank (offering letter), LoU dimasukkan dalam syarat jaminan yang harus dipenuhi oleh calon nasabah debitur. ${ }^{13}$ Artinya dengan dipenuhinya LoU dari penjamin yang telah disepakati dianggap sebagai pemenuhan jaminan oleh nasabah debitur. Dalam hal ini kedudukan LoU dipandang sebagai jaminan secara hukum oleh para pihak karena dalam hal ini pihak bank sebagai kreditur juga telah melakukan evaluasi kelayakan penjamin untuk memberikan LoU.

Dalam proposal pembiayaan yang dibuat bank sebagai kreditur memuat kelayakan jaminan dan pemberi jaminan. Artinya dalam hal ini sebelum memberikan pembiayaan bank sebagai kreditur juga telah menganalisis risiko dari LoU yang akan diberikan maupun risiko dari pemberi LoU, risiko yang dimaksud dalam hal ini adalah kelayakan LoU untuk menjamin pembiayaan yang diberikan kepada nasabah debitur. Demikian juga bank tentu akan menganalisis potensi risiko dari pemberi LoU untuk tidak memenuhi kewajibannya secara sukarela dalam hal nasabah debitur tidak memenuhi kewajibannya.

Kedudukan LoU sebagai jaminan pembiayaan ini jelas terlihat dalam esensi yang terkandung dalam LoU tersebut yakni adanya perjanjian pembiayaan antara nasabah debitur dan bank sebagai kreditur, adanya tiga pihak yang mengikatkan diri (pemberi LoU sebagai penjamin, nasabah debitur, dan bank sebagai kreditur), timbulnya pertanggungjawaban pemberi LoU karena terjadinya default pada perjanjian pokok (nasabah tidak dapat memenuhi kewajibannya kepada bank sebagai kreditur).

Jadi dalam hal ini jelas bahwa kedudukan LoU adalah sebagai jaminan yang diberikan penjamin pada pembiayaan yang diterima oleh nasabah debitur. Demikian juga jaminan yang terkandung di dalam LoU tersebut diperuntukkan untuk kepentingan bank sebagai kreditur. Kedudukan LoU disebut sebagai jaminan karena

12 Otoritas Jasa Keuangan (OJK), 'Dokumen Naskah Pembahasan Rancangan Peraturan Otoritas Jasa Keuangan (POJK) tentang Penilaian Aset dan Jaminan' (Otoritas Jasa Keuangan (OJK), Jakarta, 5 Februari 2019) 17.

13 Munir Fuady, Praktik Jaminan Perbankan di Indonesia (cet. 1, BI Publishing 2014) 63. 
jelas bahwa penjamin mengetahui adanya perjanjian pembiayaan antara nasabah debitur dan bank sebagai kreditur. Dalam hal ini jelas juga bahwa peruntukan LoU yang diterbitkan pemberi jaminan adalah untuk memberikan jaminan terhadap pemenuhan kewajiban nasabah debitur pada perjanjian pembiayaan.

Secara hukum kedudukan LoU adalah sebagai jaminan, namun persoalannya jika LoU dipandang sebagai jaminan khusus maka LoU tidak menyebutkan nilai absolut yang menjadi tanggung jawab pemberi jaminan dalam hal nasabah debitur tidak memenuhi kewajibannya pada bank sebagai kreditur. ${ }^{14}$ Tidak adanya nilai absolut atau bentuk absolut pertanggungjawaban pemberi jaminan jika nasabah debitur tidak memenuhi tanggung jawabnya menyebabkan LoU tidak dapat dikelompokkan sebagai jaminan khusus.

Dalam hal ini meskipun LoU secara khusus menunjuk pada satu kepentingan tertentu, yakni perjanjian pembiayaan antara nasabah debitur dan bank sebagai kreditur namun tiadanya nilai absolut maupun bentuk absolut pertanggungjawaban pemberi jaminan dalam hal nasabah debitur tidak dapat memenuhi kewajiban pada bank sebagai kreditur membuat LoU lebih tepat disebut sebagai jaminan umum. ${ }^{15}$ LoU dikelompokkan dalam jaminan yang bersifat umum karena meskipun perjanjian pembiayaan ditentukan secara jelas mengesampingkan Pasal 1266 dan 1267 KUH Perdata, namun dalam hal nasabah debitur nyata-nyata tidak memenuhi kewajibannya dan pemberi jaminan tidak memenuhi tanggung jawabnya secara sukarela (voluntary) dalam hal ini bank sebagai kreditur tidak dapat melakukan eksekusi secara langsung seperti jaminan khusus lainnya.

Secara hukum LoU lebih tepat dikelompokkan dalam jaminan umum karena bentuk dan nilai pertanggungjawaban yang masih abstrak. Upaya terbaik (best effort) dipandang abstrak sebagai pertanggungjawaban jaminan khusus yang merujuk pada nilai dan bentuk yang absolut. Pertangungjawaban yang abstrak (baik nilai maupun bentuk) dipandang lebih mewakili sifat jaminan umum sebagaimana diatur dalam Pasal 1131 KUH Perdata. ${ }^{16}$

\section{Persoalan Eksekusi Jaminan LoU}

Persoalan yang timbul sehubungan dengan penggunaan LoU sebagai jaminan adalah persoalan eksekusi dari jaminan LoU tersebut jika nasabah debitur tidak dapat memenuhi kewajibannya dan pemberi jaminan LoU tidak melaksanakan kewajibannya secara sukarela. Sesuai dengan surat Mahkamah Agung (MA) Nomor 427/MA/OJK.07/4/2016 yang menyatakan bahwa eksekusi jaminan LoU harus dilaksanakan melalui gugatan ke pengadilan karena nilai dan bentuk

14 Fence M. Wantu, 'Mewujudkan Kepastian Hukum, Keadilan, dan Kemanfaatan dalam Putusan Hakim di Peradilan Perdata' (2012) 12 (3) Jurnal Dinamika Hukum Universitas Jenderal Soedirman 480, 479-490.

15 Kartika Dyah Anggraeni dan Krisnadi Nasution, 'Kekuatan Hukum LoU sebagai Jaminan dalam Kredit Sindikasi Bank' (2019) 2 (2) Jurnal Hukum Bisnis Bonum Commune Universitas 17 Agustus 1945 Surabaya 185, 188.

$16 \quad$ Pasal 1131 KUH Perdata: "semua kebendaan si berutang, baik yang bergerak maupun yang tidak bergerak, baik yang sudah ada maupun yang baru akan ada di kemudian hari, menjadi tanggungan untuk segala perikatan perseorangan”, Pasal 1131 KUH Perdata ini dipandang lebih memenuhi sifat pertanggungjawaban yang abstrak dari pemberi jaminan LoU sehingga dalam konstruksi hukumnya LoU lebih tepat dikatakan sebagai jaminan umum. 
pertanggungjawaban yang belum jelas dari pemberi jaminan (penerbit LoU). ${ }^{17}$

Sebagaimana disebutkan dalam Yurisprudensi MA Nomor 1496/K/Pdt/2018 bahwa sifat LoU bukanlah claim on demand karena tidak disebutkan secara jelas nilai dan bentuk pertanggungan yang diberikan oleh penerbit LoU. Jadi dalam hal ini LoU bukanlah jaminan yang serta-merta dapat dieksekusi, melainkan bank sebagai kreditur harus menentukan batasan pertanggungjawaban penerbit LoU melalui gugatan ke pengadilan sesuai dengan surat MA Nomor 427 / MA/OJK.07/4/2016.

Artinya, jika mengacu pada surat MA tersebut maka dalam hal nasabah debitur tidak memenuhi kewajibannya kepada bank sebagai kreditur dan penerbit LoU tidak melaksanakan kewajiban penjaminannya secara sukarela maka bank sebagai kreditur harus melakukan gugatan pada kelalaian penerbit LoU untuk memenuhi kewajibannya sesuai dengan jaminan LoU yang dibuatnya. Dalam gugatan tersebut bank harus memohonkan nilai yang harus dipertanggungjawabkan oleh pemberi jaminan LoU.

Setelah pengadilan membuktikan penerbit LoU lalai dalam memenuhi kewajibannya sebagai penjamin dan dalam putusan pengadilan yang menyatakan penerbit LoU lalai melaksanakan kewajibannya dengan mengacu pada Pasal 1820 KUH Perdata dan dalam amar putusan gugatan tersebut disebutkan nilai yang menjadi tanggung jawab dari penerbit LoU maka hal itulah yang menjadi dasar bagi bank sebagai kreditur untuk mengajukan eksekusi atas pertanggungjawaban penerbit LoU sebagai penjamin, dengan syarat setelah putusan pengadilan tersebut berkekuatan hukum tetap.

Jadi dalam hal ini LoU bukanlah jaminan yang serta-merta dapat dieksekusi oleh bank sebagai kreditur, seketika dalam hal nasabah debitur gagal memenuhi kewajibannya dan penerbit LoU tidak memenuhi kewajibannya secara sukarela. Eksekusi yang dapat dimohonkan oleh bank sebagai kreditur dalam hal ini adalah eksekusi atas putusan pengadilan terkait kelalaian penerbit LoU dalam memenuhi kewajibannya. Jadi dalam hal ini bank sebagai kreditur pembiayaan yang dijamin oleh LoU dapat mengajukan eksekusi atas putusan pengadilan terhadap kelalaian penerbit LoU yang telah berkekuatan hukum tetap.

Konstruksi hukum yang dipergunakan terkait dengan sifat eksekusi dari putusan pengadilan terkait kelalaian penerbit LoU tersebut adalah teori kesalahan dan pertanggungjawaban. Artinya dalam hal ini bank sebagai kreditur harus membuktikan masing-masing kesalahan dari pihak yang digugatnya. ${ }^{18}$ Dalam hal teori kesalahan dan pertanggungjawaban maka dalam hal ini penerbit jaminan LoU tidak dapat serta-merta dimintai pertanggungjawaban mengingat kedudukan penerbit LoU secara hukum adalah penjamin. Dalam hal ini jika baik nasabah debitur tidak memenuhi kewajibannya secara sukarela maupun penerbit LoU sebagai penjamin tidak memenuhi kewajiban nasabah debitur secara sukarela maka bank sebagai kreditur tidak dapat secara serta-merta melakukan gugatan pada penjamin.

17 Surat Mahkamah Agung (MA) Nomor 427/MA/OJK.07/4/2016 merupakan jawaban dari surat OJK Nomor S-43/d.09-2015 yang mempertanyakan sifat LoU sebagai tindak lanjut dari Yurisprudensi MA Nomor 581/K/Pdt.sus/2012 dan Yurisprudensi Mahkamah Agung Nomor $1150 / \mathrm{K} / \mathrm{Pdt} / 2015$

18 Toni Prasetiyantono, Restrukturisasi Pembiayaan Bermasalah (cet. 1, BI Press 2007) 37. 
Guna melengkapi penjelasan dalam surat MA Nomor 427/MA/OJK.07/4/2016, MA dalam korespondensi dengan OJK kembali mengirimkan surat MA Nomor 551/MA/OJK.05/11/201819 yang menjelaskan secara teknis terkait gugatan dan eksekusi pada penyelesaian sengketa pembiayaan. Mengacu pada teori kesalahan dan pertanggungjawaban maka berdasarkan surat MA Nomor 551/MA/OJK.05/11/2018 pengadilan harus menyatakan nasabah debitur wanprestasi dan melakukan eksekusi jaminan khusus dan/atau jaminan umum milik nasabah debitur sebelum melakukan gugatan terhadap penerbit LoU.

Mengacu pada teori kesalahan dan pertanggungjawaban, maka secara keperdataan tanggung jawab penerbit LoU baru dinyatakan lahir setelah seluruh proses hukum atas nasabah debitur selesai (pernyataan wanprestasi dari bank sebagai kreditur dan eksekusi terhadap nasabah debitur). Upaya terbaik (best effort) tidak akan memiliki ukuran yang jelas jika belum dilakukan upaya hukum terhadap nasabah debitur, termasuk proses eksekusi yang telah berkekuatan hukum tetap.

Setelah proses hukum dan eksekusi terhadap nasabah debitur selesai dilakukan oleh bank sebagai kreditur maka akan dapat diketahui nilai piutang dari bank kepada nasabah debitur yang masih tersisa dan tidak dapat dipenuhi oleh nasabah debitur. ${ }^{20}$ Nilai piutang tersebut yang menjadi ukuran terbaik atau best effort bagi pemenuhan tanggung jawab oleh penerbit LoU sebagai penjamin. Jika dalam hal ini penerbit LoU tidak memenuhi secara sukarela untuk melunasi sisa nilai piutang tersebut maka bank sebagai kreditur baru dapat mengajukan gugatan ke pengadilan kepada penjamin, dalam hal ini penerbit LoU karena lalai tidak memenuhi jumlah yang menjadi tanggung jawabnya.

Tanpa menyatakan nasabah debitur wanprestasi serta melakukan proses eksekusi pada nasabah debitur (yang telah berkekuatan hukum tetap) maka tanggung jawab penerbit LoU belum timbul dan penerbit LoU sebagai penjamin belum dapat dinyatakan lalai untuk melaksanakan kewajibannya. Demikian juga dalam hal ini belum tentu keseluruhan nilai piutang (pinjaman yang tidak dapat dibayarkan oleh nasabah debitur) menjadi tanggung jawab penerbit LoU sebagai penjamin. Pengadilan akan memutuskan kesalahan penerbit LoU berdasarkan kelalaiannya tidak memenuhi kewajibannya sebagai penjamin. Jadi setelah bank sebagai kreditur mengusahakan pengembalian (repayment) kewajiban melalui proses eksekusi atas nasabah debitur dan nilai sisa yang tidak terpenuhi akan menjadi tanggung jawab penjamin, dalam hal ini penerbit LoU.

Proses eksekusi untuk mendapat pengembalian (repayment) dari perjanjian pembiayaan yang menggunakan LoU sebagai jaminan harus melalui dua tahap persidangan dan/atau dua tahap eksekusi. Artinya dalam hal ini jika persidangan perkara wanprestasi (perjanjian pembiayaan) maupun eksekusi terkait pertanggungjawaban nasabah debitur belum selesai (belum berkekuatan hukum tetap) maka bank sebagai kreditur tidak dapat melakukan upaya paksa terhadap pemenuhan kewajiban penerbit LoU sebagai penjamin.

19 Surat MA Nomor 551/MA/OJK.05/11/2018 merupakan jawaban dari korespondensi atas surat OJK Nomor S-17/d.02-2018 yang memohon klarifikasi atas sifat LoU yang dinyatakan bukan sebagai claim on demand sebagaimana dalam Yurisprudensi MA Nomor 1496/K/Pdt/2018.

20

Ninik Darmini dan S. I. Jenie, 'Eksistensi Jaminan dalam Kontrak Pengadaan Gabah/Beras pada Perum Bulog Divisi Regional Yogyakarta' (2006) 18 (2) Jurnal Mimbar Hukum Universitas Gadjah Mada 257, 261. 
Secara hukum bank sebagai kreditur dalam hal ini tidak dapat melakukan eksekusi atas LoU, tetapi sebagaimana telah dijelaskan cara bank sebagai kreditur untuk memperoleh pengembalian (repayment) adalah dengan melakukan gugatan atas dasar kelalaian memenuhi isi LoU dan berdasarkan putusan atas gugatan tersebut jika telah berkekuatan hukum tetap maka bank sebagai kreditur dapat mengajukan permohonan eksekusi.

Mengingat sifat LoU bukan sebagai jaminan khusus dan dasar eksekusi bank sebagai kreditur untuk memperoleh pengembalian (repayment dari piutang) adalah putusan pengadilan atas kelalaian pemenuhan isi LoU (gugatan wanprestasi) maka sifat eksekusi jaminan yang dapat dimohonkan oleh bank adalah eksekusi jaminan yang bersifat umum. Jika pengadilan telah memutuskan gugatan bank sebagai kreditur diterima maka berdasarkan nilai pertanggungjawaban penjamin sebagaimana diputuskan dalam putusan pengadilan akan dipergunakan sebagai dasar eksekusi kepada penerbit LoU sebagai penjamin. Dasar eksekusi LoU sebagai penjamin menggunakan dasar Pasal 1131 dan 1132 KUH Perdata.

Jadi secara hukum tidak dapat dilakukan eksekusi terhadap LoU karena LoU secara hukum bukanlah jaminan khusus. Jika bank sebagai kreditur akan meminta pertanggungjawaban penjamin, dalam hal ini pemberi LoU maka cara yang dapat ditempuh oleh bank adalah melakukan gugatan atas dasar wanprestasi karena kelalaian penerbit LoU sebagai penjamin untuk memenuhi kewajibannya dan nilai absolut pertanggungjawaban penerbit LoU sebagai penjamin akan menyesuaikan dengan putusan pengadilan.

Bank sebagai kreditur baru dapat menuntut pertanggungjawaban penerbit LoU sebagai penjamin setelah bank menyelesaikan seluruh proses hukum termasuk eksekusi pada nasabah debitur sesuai surat MA Nomor 551/MA/OJK.05/11/2018. Surat MA ini sudah diaplikasikan dalam praktik peradilan perdata yakni melalui Putusan Nomor 611/Pdt.G/2019/PN JKT.SEL yang menyatakan bahwa gugatan bank adalah prematur dan tidak dapat diterima jika langsung menggugat pemberi jaminan, yakni penerbit LoU tanpa adanya eksekusi terhadap jaminan umum dan khusus milik nasabah debitur.

Dalam praktik peradilan di Indonesia eksekusi terhadap pertanggungjawaban penjamin yakni penerbit LoU akan memakan tahapan dan waktu yang panjang, sesuai surat MA Nomor 427/MA/OJK.07/4/2016 dan surat MA Nomor 551/MA/OJK.05/11/2018. Persoalan panjangnya tahapan yang harus ditempuh oleh bank sebagai kreditur untuk meminta pertanggungjawaban pemberi LoU sebagai penjamin disebabkan karena dalam tata hukum Indonesia pemberian LoU dipandang sebagai pernyataan bersyarat untuk menjamin perjanjian pembiayaan antara nasabah debitur dan bank sebagai kreditur.

\section{Urgensi Evaluasi Penggunaan Jaminan LoU}

Sesuai dengan Pasal 8 ayat (1) Undang-Undang Nomor 10 Tahun 1998 tentang Perubahan atas Undang-Undang Nomor 7 Tahun 1992 tentang Perbankan (UU Perbankan) mengatur bahwa dalam memberikan kredit, bank wajib mempunyai keyakinan berdasarkan analisis yang mendalam atas iktikad dan kemampuan serta kesanggupan nasabah debitur untuk melunasi utangnya sesuai dengan yang diperjanjikan. Selanjutnya terkait dengan agunan dan jaminan diatur dalam 
penjelasan Pasal 8 ayat (1) "untuk memperoleh keyakinan tersebut, sebelum memberikan kredit, bank harus melakukan penilaian yang seksama terhadap watak, kemampuan, modal, agunan...”.21

Selanjutnya mengacu pada Pasal 29 ayat (3) UU Perbankan mengatur bahwa dalam memberikan kredit, bank wajib menempuh cara-cara yang tidak merugikan bank dan kepentingan nasabah yang memercayakan dananya kepada bank. Dalam hal ini jika melihat penggunaan jaminan LoU dalam praktik perbankan sangat merugikan bank sebagai kreditur karena LoU bukanlah jaminan khusus yang dapat dipergunakan sebagai jaminan untuk mendapat pengembalian (repayment) jika nasabah debitur tidak memenuhi kewajibannya.

Demikian juga proses hukum yang terlalu panjang bagi bank untuk meminta pertanggungjawaban penerbit LoU sebagai penjamin dalam hal ini juga merugikan posisi bank sebagai kreditur. Pada prinsipnya jaminan dalam perjanjian pembiayaan pada esensinya dipergunakan untuk memberi pengembalian (repayment) pada bank sebagai kreditur yang memiliki kepentingan untuk segera mendapat pengembalian (repayment) ketika nasabah debitur tidak dapat memenuhi kewajibannya dan penjamin tidak melaksanakan fungsinya secara sukarela. ${ }^{22}$

Demikian juga jika dilihat secara hukum kedudukan jaminan LoU juga sangat lemah, dengan kondisi pertanggungjawaban pemberi jaminan hanya berdasarkan pada upaya terbaik dengan ukuran yang ditetapkan melalui putusan pengadilan maka kondisi ini akan melemahkan bank sebagai kreditur yang memiliki kepentingan untuk segera mendapat pengembalian. Seharusnya jika tujuan bank sebagai kreditur pada penggunaan jaminan adalah pengembalian (repayment) dalam waktu singkat jika nasabah tidak memenuhi kewajibannya maka seharusnya bank sebagai kreditur menggunakan jaminan yang bersifat claim on demand.

Dengan memperhatikan fakta yang ada terkait penggunaan jaminan maka dalam hal ini penggunaan jaminan LoU perlu dievaluasi, dengan tujuan agar penggunaan jaminan LoU tidak merugikan bank sebagai kreditur sebagaimana diatur dalam Pasal 29 ayat (3) UU Perbankan. Demikian juga jika mengacu pada POJK Nomor 18/POJK.03/2016 tentang Manajemen Risiko bagi Bank Umum, dalam POJK tersebut salah satu isinya dalam poin ketiga adalah terkait settlement risk yakni risiko tidak dapat dilakukan penyelesaian baik secara sukarela oleh nasabah debitur maupun penjamin pada tanggal yang telah ditetapkan atau risiko penyelesaian (settlement) melalui upaya yang dimungkinkan.

Tidak terpenuhinya kehati-hatian perbankan dalam penggunaan LoU sebagai jaminan pembiayaan disebabkan karena jika tujuan adanya jaminan dalam pembiayaan perbankan adalah untuk jaminan pengembalian (repayment) pada bank sebagai kreditur maka seharusnya jaminan yang dipergunakan adalah yang bersifat claim on demand. Tujuannya agar ada kepastian hukum bagi bank sebagai kreditur untuk mendapat pengembalian (repayment) jika nasabah debitur maupun penerbit LoU sebagai penjaminnya tidak memenuhi kewajibannya.

Bank sebagai kreditur memerlukan jaminan yang bersifat claim on demand karena bank sebagai kreditur membutuhkan jaminan dengan nilai pengembalian

21 Pasal 8 dan penjelasan Pasal 8 UU Perbankan tersebut merupakan penjabaran dalam prinsip kehati-hatian perbankan (prudential banking).

22 Hessel and King, Financing Case (ed. 1, Mc Graw Hill Book Publishing 2011) 94. 
yang absolut, mengingat piutang bank bersifat absolut dan jumlah kewajiban debitur juga bersifat absolut. Tidak terpenuhinya prinsip kehati-hatian perbankan (prudential banking) yang sangat berpotensi merugikan bank sebagai kreditur adalah menjamin utang (kewajiban) nasabah yang bersifat absolut dengan jaminan yang bersifat upaya terbaik (tidak absolut).

Pengertian tidak bersifat absolut dalam hal ini karena sifat eksekusinya tergantung pada nilai yang ditetapkan dalam putusan pengadilan dan dalam hal ini nilai yang ditetapkan dalam putusan pengadilan tersebut dapat berbeda dengan nilai yang menjadi kewajiban penerbit LoU sebagai penjamin yang seharusnya bersifat absolut. Jadi dalam hal ini kalangan perbankan maupun utamanya OJK sebagai regulator harus melakukan evaluasi terhadap penggunaan jaminan LoU dalam perjanjian kredit pembiayaan, utamanya perjanjian kredit pembiayaan yang berskala besar.

Sutan Remy Sjahdeini dalam Toto Octaviano Dendhana, menguraikan bahwa beban risiko bank jauh lebih besar utamanya setelah dana dalam perjanjian pembiayaan dikuasai oleh nasabah debitur oleh sebab itu bank memerlukan jaminan yang kuat untuk menjamin pengembalian dan pemenuhan kewajiban debitur maupun penjaminnya. ${ }^{23}$ Kondisi sebagaimana diuraikan oleh Sutan Remy Sjahdeini dalam Toto Octaviano Dendhana tersebut merupakan kondisi yang alamiah atau natural akan terjadi pada perjanjian pembiayaan sehingga adanya jaminan yang kuat merupakan sesuatu yang mutlak harus dipenuhi.

Dalam hukum perbankan yang dimaksud kondisi yang seimbang antara bank sebagai kreditur dan nasabah debitur adalah adanya keseimbangan antara nilai pembiayaan yang diberikan oleh bank kepada nasabah debitur dan sebaliknya jaminan yang diberikan oleh nasabah debitur kepada bank selaku kreditur. Prinsipprinsip keseimbangan tersebut juga diatur dalam POJK Nomor 18/POJK.03/2016 tentang Manajemen Risiko bagi Bank Umum yang mengharuskan adanya kehatihatian dan analisis yang cermat dalam pemberian kredit termasuk aspek risiko.

Penggunaan LoU sebagai jaminan dalam pembiayaan akan membuat posisi bank sebagai kreditur dirugikan, mengingat kepastian hukum dari pemegang jaminan LoU sangat rendah. Demikian juga penggunaan LoU sebagai jaminan, utamanya jika LoU dipergunakan sebagai jaminan pembiayaan yang bersifat tunggal maka akan merugikan posisi bank sebagai kreditur karena jaminan yang diberikan oleh nasabah bersifat tidak absolut (hanya berdasarkan upaya terbaik), sedangkan pembiayaan yang telah diterima nasabah bersifat absolut (memiliki nilai absolut).

Jaminan LoU menyebabkan kedudukan bank sebagai kreditur dan nasabah debitur maupun penjaminnya menjadi tidak seimbang. Letak ketidakseimbangan dalam hubungan tersebut adalah terhadap pembiayaan yang bersifat absolut (kewajiban debitur dapat dihitung secara pasti) namun nasabah debitur hanya memberikan jaminan dengan dasar upaya terbaik (best effort) tanpa bentuk tanggung jawab absolut dari penjamin, sehingga ketika nasabah debitur tidak dapat memenuhi tanggung jawabnya maupun penerbit LoU sebagai penjamin tidak melakukan fungsinya secara sukarela maka bank sebagai kreditur berada dalam

23 Toto Octaviano Dendhana, 'Penerapan Prudential Banking Principle dalam Upaya Perlindungan Hukum bagi Nasabah Penyimpan Dana' (2013) 1 (1) Jurnal Lex Et Societatis Universitas Sam Ratulangi 40. 
posisi yang dirugikan.

Dalam rangka memberikan kepastian hukum pada bank sebagai kreditur serta dalam rangka mewujudkan hubungan yang seimbang dalam perjanjian kredit pembiayaan maka OJK perlu melakukan penataan sebagai bentuk evaluasi penggunaan LoU sebagai jaminan dalam POJK. Urgensi untuk melakukan penataan terhadap jaminan tersebut diatur dalam POJK Nomor 42/POJK.03/2017 tentang Kewajiban Penyusunan dan Pelaksanaan Kebijakan Perkreditan atau Pembiayaan Bank bagi Bank Umum.

OJK selaku regulator harus melakukan evaluasi terhadap LoU sebagai jaminan kredit pembiayaan, mengingat sifat penggunaan LoU tersebut sangatlah merugikan bank sebagai kreditur dan akan menimbulkan hubungan yang tidak seimbang antara bank sebagai kreditur dan nasabah debitur maupun penjaminnya. Evaluasi terhadap penggunaan LoU sebagai jaminan tersebut harus ditindaklanjuti dengan penuangan ketentuan hasil evaluasi dalam POJK.

Secara hukum, dalam hal ini OJK memiliki momentum untuk melakukan evaluasi terhadap penggunaan LoU sebagai jaminan dengan memperhatikan POJK Nomor 42/POJK.03/2017 dan melalui POJK Nomor 15/POJK.03/2017 tentang Penetapan Status dan Tindak Lanjut Pengawasan Bank Umum. Artinya dalam hal ini jika penggunaan LoU merugikan bank sebagai kreditur maka berdasarkan POJK Nomor 15/POJK.03/2017, OJK sebagai regulator harus menentukan tindak lanjut dari fakta yang seharusnya muncul pada saat kegiatan pengawasan tersebut.

Jika mengacu pada POJK Nomor 42/POJK.03/2017 maka hasil pengawasan tersebut harus dituangkan dalam prosedur kebijakan masing-masing bank dalam pemberian kredit pembiayaan. Penataan jaminan ini memiliki urgensi terhadap tingkat kesehatan setiap bank dalam operasionalnya. Jika jaminan LoU tetap dipergunakan sebagai jaminan dan utamanya jaminan tunggal maka jika timbul kredit bermasalah (non performing loan) akan semakin merugikan bank sebagai kreditur karena bank tidak dapat melakukan recovery asset disebabkan oleh jaminan yang tidak dapat dieksekusi dan akibatnya akan berdampak pada likuiditas bank sebagai kreditur.

Urgensi perlunya evaluasi atas penggunaan jaminan LoU dalam praktik pembiayaan perbankan juga mengacu pada Peraturan Bank Indonesia (PBI) Nomor 14/15/PBI/2012 tentang Penilaian Kualitas Aset Bank Umum. Tujuan jaminan dalam pembiayaan adalah sebagai jaminan recovery (pengembalian dan pemulihan) pada aset perbankan jika pembiayaan yang diberikan tersebut berstatus sebagai kredit bermasalah (non performing loan). ${ }^{24}$ Jaminan akan berfungsi sebagai alat recovery terhadap kualitas dan aset perbankan sebagaimana dimaksud dalam PBI Nomor 14/15/PBI/2012.

Pada akhirnya untuk menciptakan jaminan keseimbangan dalam pemberian perjanjian kredit maka OJK sebagai regulator perlu melakukan evaluasi atas penggunaan LoU sebagai jaminan pembiayaan. OJK harus dapat mengembalikan hakikat jaminan sebagai alat pengembalian dan pemulihan yang efektif sehingga tidak merugikan bank sebagai kreditur. Mengingat jika fungsi perkreditan bank terganggu maka akan mengganggu fungsi intermediary bank secara keseluruhan.

$24 \quad$ Samual Kitt, Guarantee Agreement (ed. 1, Irvin Books Publishing 2010) 104. 


\section{PENUTUP}

Jaminan LoU hanya dipandang janji dari penerbit LoU sebagai penjamin namun janji tersebut bersifat abstrak karena tidak disertai dengan nilai pertanggungjawaban absolut dari penjamin. Tiadanya nilai pertanggungjawaban yang absolut dari penjamin juga menyebabkan persoalan eksekusi pada jaminan LoU. Dalam hal terjadi cidera janji, maupun nasabah debitur tidak dapat memenuhi kewajibannya maka bank sebagai kreditur tidak dapat secara serta-merta melakukan eksekusi pada jaminan LoU.

Tidak dapat dilakukannya eksekusi pada jaminan LoU disebabkan karena tidak ada nilai absolut yang dijamin pada jaminan LoU sehingga dalam hal ini batasan tanggung jawab dari penerbit LoU tidak dapat ditentukan secara serta-merta oleh sebab itu pengadilan tidak dapat mengeksekusi jaminan LoU. Tidak dapat dieksekusinya jaminan LoU secara langsung oleh bank sebagai kreditur dalam hal nasabah debitur cidera janji dan tidak dapat memenuhi kewajibannya dalam perjanjian pembiayaan tentu sangat merugikan bank sebagai kreditur. Demikian juga dengan mekanisme pertanggungjawaban penerbit LoU sebagai penjamin sebagaimana diterangkan dalam surat MA Nomor 551/MA/OJK.05/11/2018 membuat bukan saja jaminan LoU tidak dapat dieksekusi tetapi juga menimbulkan kendala bagi bank sebagai kreditur untuk menuntut pertanggungjawaban penerbit LoU sebagai penjamin.

\section{DAFTAR REFERENSI}

\section{Buku}

Fuady M, Praktik Jaminan Perbankan di Indonesia (cet. 1, BI Publishing 2014).

Hessel and King, Financing Case (ed. 1, Mc Graw Hill Book Publishing 2011).

Kitt S, Guarantee Agreement (ed. 1, Irvin Books Publishing 2010).

Morisson, et. al, Harvard Business Law Dictionary (ed. 1, Harvard Book Publishing 2000).

Peter H, Legal Aspect on Financing Transaction (ed. 5, Little Brown Publishing 2009). Prasetiyantono T, Restrukturisasi Pembiayaan Bermasalah (cet. 1, BI Press 2007).

Suhardi G, Usaha Perbankan dalam Perspektif Hukum (cet. 1, Kanisius 2003).

\section{Jurnal}

Anggraeni KD dan Nasution K, 'Kekuatan Hukum LoU sebagai Jaminan dalam Kredit Sindikasi Bank' (2019) 2 (2) Jurnal Hukum Bisnis Bonum Commune Universitas 17 Agustus 1945 Surabaya.

Darmini N dan Jenie SI, 'Eksistensi Jaminan dalam Kontrak Pengadaan Gabah/Beras pada Perum Bulog Divisi Regional Yogyakarta' (2006) 18 (2) Jurnal Mimbar Hukum Universitas Gadjah Mada.

Dendhana TO, 'Penerapan Prudential Banking Principle dalam Upaya Perlindungan Hukum bagi Nasabah (2013) 1 (1) Jurnal Lex Et Societatis Universitas Sam Ratulangi. 
Elmiyah N dan Sujadi S, 'Upaya-upaya Hukum terhadap Penetapan' (2005) 35 (3) Jurnal Hukum dan Pembangunan Universitas Indonesia.

Jened R, 'Catatan Hukum Kritis Pembiayaan Sekunder Perumahan' (2019) 31 (1) Jurnal Mimbar Hukum Universitas Gadjah Mada.

Johan S dan Ariawan, 'Keterbukaan Informasi UU Pasar Modal Menciptakan Asymmetric Information dan Semi Strong Form' (2021) 50 (1) Jurnal Masalahmasalah Hukum Universitas Diponegoro.

Kusumadewi Y, 'Pelaksanaan Prinsip Piercing The Corporate Veil dalam Perseroan Terbatas menurut Undang-Undang Nomor 40 Tahun 2007 tentang Perseroan Terbatas' (2019) 8 (1) Jurnal Binamulia Hukum Universitas Krisnadwipayana.

Ramelan Y, 'Perlindungan terhadap Simpanan Pernah Tercatat pada Bank, Bukan Suatu Keniscayaan' (2019) 49 (4) Jurnal Hukum dan Pembangunan Universitas Indonesia.

Wantu FM, 'Mewujudkan Kepastian Hukum, Keadilan, dan Kemanfaatan dalam Putusan Hakim di Peradilan Perdata' (2012) 12 (3) Jurnal Dinamika Hukum Universitas Jenderal Soedirman.

\section{Dokumen Resmi/Surat}

Bank Himbara dan otoritas jasa keuangan (OJK), 'Notulen rapat kerja antara bank Himbara dengan otoritas jasa keuangan (OJK), dengan agenda tindak lanjut non performing loan (NPL)' (Bank Himbara dan OJK, Jakarta, 15 Januari 2020).

Otoritas Jasa Keuangan (OJK), 'Dokumen Naskah Pembahasan Rancangan Peraturan Otoritas Jasa Keuangan (POJK) tentang Penilaian Aset dan Jaminan' (Otoritas Jasa Keuangan (OJK), Jakarta, 5 Februari 2019) 17.

Surat Mahkamah Agung Nomor 427/MA/OJK.07/4/2016.

Surat Mahkamah Agung Nomor 551/MA/OJK.05/11/2018.

Surat Otoritas Jasa Keuangan Nomor S-43/d.09-2015.

Surat Otoritas Jasa Keuangan Nomor S-17/d.02-2018.

\section{Putusan Pengadilan}

Putusan Mahkamah Agung Nomor 581/K /Pdt.sus/2012.

Putusan Mahkamah Agung Nomor 1150/K/Pdt/2015.

Putusan Mahkamah Agung Nomor 1496/K/Pdt/2018.

Putusan Pengadilan Negeri Jakarta Selatan Nomor 611/Pdt.G/2019/PN JKT.SEL.

\section{Peraturan Perundang-Undangan}

Kitab Undang-Undang Hukum Perdata.

Undang-Undang Nomor 7 Tahun 1992 tentang Perbankan, sebagaimana diubah dengan Undang-Undang Nomor 10 Tahun 1998 tentang Perubahan atas Undang-Undang Nomor 7 Tahun 1992 tentang Perbankan.

Peraturan Bank Indonesia Nomor 3/10/PBI/2001 tentang Penerapan Prinsip Mengenal Nasabah. 
Peraturan Bank Indonesia Nomor 14/15/PBI/2012 tentang Penilaian Kualitas Aset Bank Umum.

Peraturan Otoritas Jasa Keuangan Nomor 18/POJK.03/2016 tentang Manajemen Risiko bagi Bank Umum.

Peraturan Otoritas Jasa Keuangan Nomor 15/POJK.03/2017 tentang Penetapan Status dan Tindak Lanjut Pengawasan Bank Umum.

Peraturan Otoritas Jasa Keuangan Nomor 42/POJK.03/2017 tentang Kewajiban Penyusunan dan Pelaksanaan Kebijakan Perkreditan atau Pembiayaan Bank bagi Bank Umum. 
